\title{
Initial PracticalTraining Trends of Primary School Teachers: The Private School Model. Comparative Study in Mediterranean Europe ${ }^{1}$
}

\section{Leoncio Vega Gil}

J. María Hernández Díaz

Clementina García Crespo

L. Belén Espejo Villar

Bienvenido Martín Fraile

J. Carlos Hernández Beltrán

Luján Lázaro Herrero

University of Salamanca

\section{ABSTRACT}

This paper analyzes from a comparative perspective the initial training of primary school teachers in four Mediterranean European countries (France, Italy, Spain and Portugal). These four countries present certain common characteristics of cultural, social, political and economic order, but also remarkable differences in their education systems and in their approaches to teacher training. This study focuses on practical training as a key element in teacher preparation, which often does not receive the level of attention it deserves. Training paradigms and their inclusion in private management and administration systems are also taken into account.

Key words: teachers' training, practical training, comparative methodology

\section{RESUMEN}

Este artículo analiza, desde una perspectiva comparada, la formación inicial de los profesores de educación primaria en cuatro países europeos mediterráneos (Francia, Italia, España y Portugal), que, junto a ciertas características comunes de orden cultural, social, político y económico, presentan notables diferencias en sus sistemas educativos y las formas de abordar la formación de los profesores. La comparación se centra, especialmente, en la preparación práctica, un aspecto tan esencial como, a menudo, falto de una consideración suficiente. La comparación tiene en cuenta, igualmente, los paradigmas de formación y sus inclusión en sistemas privados de gestión y administración.

Descriptores: formación de profesores, formación práctica, metodología comparada

\section{RÉSUMÉ}

Ce papier analyse à partir d'une perspective comparative la formation professionnelle initiale des enseignants à l'école primaire dans quatre pays de l'Europe méditerranéenne (France, Italie, Espagne et Portugal.) Ces quatre pays présentent certaines caractéristiques communes d'ordre culturel, social, politique et économique, mais aussi des différences marquées dans leurs systèmes 
d'éducation et leurs approches de la formation professionnelle des enseignants. Cette étude se concentre sur la formation pratique comme élément clé dans la préparation des enseignants, qui souvent ne reçoit pas l'attention qu'elle mérite. Les paradigmes de formation professionnelle et leur inclusion dans la gestion privée et les systèmes administratifs sont aussi pris en considération. Mots-clés: formation professionnelle des enseignants, formation pratique, méthodologie comparativee

\section{Introduction}

$\mathrm{C}$ ONSIDERABLE ATTENTION HAS BEEN FOCUSED on teacher training in recent decades and clearly shows that the old concepts of "school based training" have disappeared (García Garrido, 1998, p. 29). It is now widely accepted that progress in societies largely depends on education, which in turn relies on the quality of teachers. Education in the twenty-first century school is more than a command of teaching skills and the transmission of knowledge. Multi-cultural education, new technologies and the impact of the media must also be taken into account in designing teacher education programmes.

We have focused our attention on practical training, an aspect of teacher education which has been partly overlooked by training institutions, which place greater emphasis on academic aspects. Practical training has always been part of teacher education, but today it is especially relevant given the development of new education policies and new models of teacher education. Central to the current debate are questions such as the importance of practical experience during training and its inclusion in the formal curriculum, the personal and institutional link with teachers and schools at non-university level and the formalization of the role of the supervisor.

Another central concept dealt with in the present study concerns the establishment of training paradigms and their inclusion in private management and administration systems, thus enabling the supervision of education services of different types, including, in some cases, public schools. Teachers trained at private institutions are not necessarily restricted to working in private schools and may be employed in either the private or the public sector. It may well be of interest to establish whether there is a connection in the private sector.

Finally, it should be emphasised that the present study falls within the theoretical parameters of comparative research whose aim is not only to reflect on the multiple elements which underlie the conformation of policies of convergence in countries which share cultural and geographical similarities, but which also carry out self-examination in each of the education systems analyzed. (Whitty, Power, Halpin, 1999:19). This comparative study was carried out in four European Mediterranean countries (France, Italy, Spain and Portugal) and presents certain common characteristics of a cultural, social, political and economic order, but there are also notable differences which can be seen in their respective education systems and also in teacher education approaches. The marked historical influence of France on the other countries must be taken into account when comparing the four systems which are the subject of this study. In the variables studied, homogeneity, essential in all comparison, has been scrupulously respected. 


\section{Schooling in the private sector}

The management and provision of education services in their various forms have in recent years become a matter for reflection both at international and national levels. It is also important that the increasing influence of market forces on pubic education policy should also be taken into account. Unsurprisingly therefore, a variety of concepts and expressions in relation to choice in education has emerged.

Given that the main object of the present study is research into the training of teachers in the private sector, it includes a section devoted to the analysis of publicfunded private schooling. The institutional or social commitment to either one of these sectors is motivated by cultural, social, ideological and/or financial considerations. This should not be overlooked when attempting to attribute the teacher education systems under study to the various models of choice of education. The choice of a private school has nothing to do - as it did up until a few decades ago - with the schooling conditions and quality offered by these sorts of schools.

As a consequence of the current prevailing economic liberalism, the use of terms appropriate to efficiency-driven or neo-liberal policies is signaling a rupture between the provision of the service and its financing and, as the current terminology suggests, is conceived of as an efficient, effective and professional response to the inadequate management of the public systems and as an alternative to state interventionism (Tooley, 2002).

Nevertheless, it should not be understood that market ideology has found its way into the field of education, that government no longer controls aspects such as the choice of investors, standardization of quality of the service or education expenditure.

A more detailed country-by-country analysis establishes some of the peculiarities and characteristics of the education systems studied, such as the management approaches of the different Education Departments.

In the case of France, the provision of education service options is not conceived as mutually exclusive but rather complementary, allowing families greater choice and to seek academic achievement. Langouet and Leter (2002) hold that one of the main reasons for choosing a particular type of education has to do with academic standards rather than moral and/or personal convictions.

Likewise, in France the majority of private schools are religious (mainly Catholic) and, by agreement with the State, receive financial aid to meet the costs both of the teaching staff and of teacher education, initial training as well as continuing professional development. Private schools which opt for the contract must adhere to the same timetables and study plans which apply to public schools and must undergo state inspection. The source of this formula is to be found in the Debré Law of 1959 which establishes the option of either a "simple" contract with the State, or partnership with the State. The contract was maintained under the laws of 1977 and 1983, and continued under the socialist reforms of the "projet Savary". It was withdrawn under F. Mitterand in 1984. 
With respect to the total number of pupils in compulsory education (10 years, from ages 6 to 16), the percentage of pupils enrolled in private schools in 1997-98 was $12.5 \%$ for pre-school education, $14.7 \%$ for primary and $20.6 \%$ for secondary.

Italy also recognises the right to education and the freedom to create schools, although the latter is not as widespread as in France. In Italy there are private schools at all levels of the education system, run by individuals or groups, where fees are charged. In some cases the qualifications provided are not officially recognised, and in the case of primary teaching, authorization is required.

Another case is where schools are officially recognised. For primary teaching the schools may be authorised by the Provincial Director (scuola sussidiate) or recognised by the State and are equivalent in category to the public schools (scuola parificate), which are responsible to the local authority. In the case of recognised schools, the curriculum and training must comply with the current regulations for State schools. Primary schools are free of charge. The much acclaimed formula of the so-called "equality schools" has not received the appropriate legal recognition. For the nine-year compulsory education period (from 6 to $15^{2}$ years old ${ }^{3}$ ), the private sector handles $7.8 \%$ of students at primary level and $4.1 \%$ at the lower secondary level.

In the case of Portugal, the private schooling model presents a number of peculiarities compared to other countries. The sector represents $11 \%$ of the total. The privately owned schools and cooperatives are established and managed by private individuals or groups.

Where collective teaching is provided according to the objectives established by the national education system, the schools have the right to the same advantages as the public schools. In accordance with the General Law on the Education System of October 1986 (Lei de Bases do Sistema Educativo) together with the modifications incorporated by the Law 115/97 of 19th September, compulsory education lasts nine years, from the age of six to fifteen. Private higher education leads to the "Bachaler", a fouryear qualification or to the "Licenciatura", a five-year degree. The curriculum of the latter is more demanding and is geared towards scientific and technical training and professional specialization.

The origin of the disjuncture between public and private education in Spain has traditionally been associated with the strong influence of the Catholic Church which managed to bring about a situation whereby the concept of the private school has been associated with a school for the elite, or of educational excellence, until the last third of XX century.

The explicit recognition of the constitutional precepts of freedom to create schools meant not only the acceptance of a dual network of public and private schools, but also the granting of public funds to finance private establishments. This policy, legitimised and consolidated by means of the Basic Law of the Right to Education of 1985, was the result of from negotiations and agreements between the Church and the State, although some of the terms of the agreements have not yet been complied with by the state-subsidised private schools.

Thus, the private schools in Spain (mainly religious and Catholic) may or may not be state subsidised. Those which do not receive public funding are given a general 
authorization and enjoy the freedom to run their school, select teaching staff, organise their curricula and manage their finances. The state-funded private schools must adhere to certain requisites laid down in the general education regulations, such as the obligation to provide education without charge. They must establish governing commissions and ensure the representation and participation of all concerned. They must establish student entry requirements which are similar to those of the public schools and maintain the average student/teacher ratio established by the education authorities and meet the requirements for curriculum planning and evaluation.

With regard to the data for schooling, the General Basic Law for the Education System of 1990 (LOGSE) states that the period of compulsory schooling is ten years, from the age of 6 to 16. For the academic year 2004-2005, according to the State School Council figures, $33.4 \%$ of primary school pupils and $33.75 \%$ of secondary school pupils were enrolled in private schools. Of the Autonomous Communities, the greatest difference between enrolment at public and private schools is to be found in Andalucía, the Canary Islands, Castilla-La Mancha and Extramadura, where at least three times as many students are enrolled at public schools as at private ones. The Autonomous Communities with the highest number of students in the private sector are, in the following order: The Basque Country, Madrid and Catalonia. The Basque Country is the only Autonomous Community in Spain in which there are more students at private schools than at public schools. From these data it can be seen that the regions in Spain with a higher standard of living are those in which there are the greatest number of private state-funded schools.

\section{Teacher Education Models}

In recent decades the education of teachers has become a question of considerable importance in European Union countries ${ }^{4}$ and as a result teacher education has been upgraded to university degree or to a higher education level in cases where it had been considered as secondary level, the objective being to provide a more solid and rigorous training for those wishing to enter the teaching profession.

Although it is not our intention to carry out an exhaustive analysis of the conceptual elements underlying the epistemological construction of the teaching profession, some of the parameters which contribute to defining teacher training might be mentioned (Tardif, 2004:185):

1. Acquisition of the basic scientific principles of teaching practice by means of formal, specialised knowledge.

2. Post-graduate university training aimed at achieving a professional profile defined by the theory of educational practice based on education research.

3. Theoretical content focused on resolving classroom situations and on the acquisition of practical teaching skills.

4. Formalization of a wide framework of demands in accordance with the level of professionalism required of the teaching profession. 
5. Self-management of knowledge acquisition and capacity for reflection on personal teaching skills.

6. Updating of scientific competency by means of continuing professional development.

This broad account of an approach to teacher education highlights the importance of an open model of teacher training, unlike training paradigms such as a specific model or that based in the school (García Garrido, 1998). The open model is clearly favorable to new developments in the profession and to the permanent establishment of the university as the training institution.

With regard to curriculum design, we can explain the configuration of some models of training which are, in fact, models of teachers and teaching. Firstly, there is the traditional model (based on classroom teaching experience), then, the reflective model (reflection in action and dynamic, open and flexible classroom performance) and thirdly, there is the model based on the concept of the teacher as researcher (the classroom being the area where curriculum research takes place). This position is defended by J. Gimeno Sacristán.

In this reconstruction of the basics of the profession it will be noted that, unlike the French model, there is concern with simultaneously developing theoretical and practical dimensions, with the objective of acquiring professional skills through greater and more direct contact with the realities of education. It should be kept in mind that the challenge of recent years has been to design and implement on-going, participative professional development plans which combine scientific knowledge with a renewed, innovative focus on education research (Cochran y Lytle, 2002).

The analysis of the following cases is carried out using three variables: legal aspects and questions of administration, institutional developments and characterization and finally, general guidelines for curriculum design. Special attention is given to initial practical training.

\section{The Case of France}

The fundamentals of the general regulations on the functioning of private teacher training institutions are stipulated in La Loi d'Orientation sur l'Éducation, 1989 and, more specifically, the legal requirements are set out in the decree of 21 st September 1992 under which these centres operate by means of a contract with the State (renewed every four years). These contracts establish specific questions related to academic organization.

Private centres in France are mainly in the hands of Catholic religious orders, Marianists, Jesuits, etc. For this reason we concentrate on the Catholic network in the present study. There are 24 Catholic education establishments throughout France which coincide roughly with the Académies or Regional Education Authorities. (In the case of the public centres, administration by the Académies is strictly according to Region). Given that these centres are financed and authorised by the State, (directly provided with funds for the salaries of the teaching staff and for the running of the centres), their internal organization is very similar to that of public centres and depends on the 
Rectorat (education offices of the Académie). The private system is therefore parallel to the public one and functions by means of a contract with the State.

These training establishments are known as Centres de Formation Pédagogiques Privés (CFPPs), or private teacher training centres, and work in close cooperation with the Catholic Centres of Education Research and Training and with the Diocesan Board of Catholic Education.

Three aspects of the design of the training curriculum should be noted: the selection process, cultural and pedagogical content of the training course and practical training. Five filters are applied in selection of candidates: completion of questionnaires for French and mathematics, a pre-training written assignment on a topic related to education, an interview with a psychologist and finally, the ideological filter to establish the candidate's personal convictions. This is the main point as unsuitability in this matter would invalidate the candidate for future professional practice.

Regarding the cultural and pedagogical training, three elements should be noted: the various disciplines, general topics and the theory and practice of teaching.

\begin{tabular}{l|l|l|l}
\hline \multirow{2}{*}{ Disciplinary Areas } & \multicolumn{3}{|c}{ HOURS } \\
\cline { 2 - 4 } & First Year & Second Year & Total \\
\hline General Education & 134 & 108 & 242 \\
Personal Education & 70 & 145 & 215 \\
Disciplinary Education & 282 & 390 & 582 \\
Theory-Practice Relationship & 6 weeks & 13 weeks & 19 weeks \\
Religious Sciences & 12 & 36 & 48 \\
\hline
\end{tabular}

Some explanations and observations on the above table should be made. Firstly, we would mention general education. Of the three subject blocks it is presented in, philosophy, sociology and educational psychology, $42 \%$ of teaching hours are devoted to the first. These subjects are taken in the first year. Concerning personal training, 65\% of the time is devoted to "analyzing professional practice", to "preparing and exploring teaching practice" and to "presenting methodology of the professional report". The greater part of this area is covered in the second year. The timetable for training in the disciplines is quite well balanced over all the internal areas (French language, mathematics, history, science, etc.), although mainly in the second year: $48 \%$ in first year and $67 \%$ in second. Although these subjects do not include a pedagogical perspective in the subject denominations, we believe that in practice they are included.

The cultural subjects offered in these training centres focus on curriculum coordinates such as languages (English and Spanish), literature (genres and periods) and stories. In the experimental area (mathematics, science and technology subjects), music and corporal expression, dance, history of music, French songs; in the area of humanities, the French Revolution, history, discoveries, etc. and French language. However, most weight is given to mathematics, science, history and literature. 
The pedagogical aspect covers psycho-sociological subjects such as organisation, classroom management and analysis of practical classroom experience, child and adolescent psychology, learning theory, the French education system, the great educators, the teaching of European languages, the European education system, transition between stages and the harmonization of knowledge.

Here, two aspects of curriculum design should be borne in mind. On the one hand, the fact that the curriculum has been structured in accordance with the ECTS (European Credits Transfer System) indicates that forms and procedures of implementation depend on the teacher-student methodological relationship. On the other hand, the French model of primary teacher training, unlike the Spanish model, provides a general rather than specialist training.

The practicum in the second year is sequenced according to the following model: 9 weeks of autonomous teaching practice in three stages ("stage en responsabilité), one week for writing the practicum report, another week of practical experience in the Collège in workshops and a final week working within one of the so called Z.E.P. (Zone d'éducation prioritaire) schools. ${ }^{5}$ The student is now a teacher-in-training ("professeur des êcoles stagiaire") and receives monthly payment, the rate being set by the State for both public and private models.

Once the student has successfully passed the concours (competitive examinations) $s /$ he goes into the second year of training to further his/her professional knowledge and skills. In fact, the student has already received 6 weeks practical experience in the first year. This involves supervised teaching practice and is carried out in all three stages of primary education. The second year, as we have already seen, is not devoted exclusively to teaching practice. The students also receive instruction at the teacher training centre in teaching methodology for the subjects in the curriculum, for the preparation and writing of the practicum report as well as other specific subjects, such as sexuality in childhood. In fact the student spends more time at the teacher training centre than at the school assigned for teaching practice. Thus, in terms of teacher training methodology, this model is fundamentally simultaneous, although not exclusively so. From a structural point of view, the practicums are organised according to specialities or areas, referred to as "projects" (mathematics, reading, etc.) Students' practical experience is organised progressively according to the three stages of primary schooling. The stages are as follows: CI (3-6 years old), CII (6-8 years old) and CIII (9-11 years old).

The content of practical training is of interest as well as the model. As we have already pointed out, practicums are spread over the two-year course, although they mostly take place in the second year and throughout the whole of that year, normally one week in September, two in November, two in March, two in April and two in May. Individual work and the remaining weeks of practicums are divided between January, February and April. Preparation and sequencing of the practical sessions are carried out at the teacher training centre. Primary school subjects dealt with are French, mathematics, physical education, art, music and foreign languages, history and geography, science, audio-visual design/education and adaptation and integration of pupils with special needs. The preparation of these sequences (called "projects") are validated (authorised) in writing according to the criteria of appropriateness, coherence, clear 
argument, presentation, creativity, level of theoretical content and reflection on the training provided to the student. This validation of the preparation and sequences is recorded in the "dossier individual pour la validation de la formation" (this is an official certificate) and concludes with a final evaluation of the student and a statement of aptitude by the centre. With regard to the content, we have also pointed out that during the first year of teaching practice the student observes and receives guidance. In second year s/he takes over for some weeks from the class teacher, who is free to attend further training courses or take other classes. These practicums are accompanied by sessions for preparation and for discussion and reflection which take place at the training centre under the permanent supervision of the tutor who, as we have seen, evaluates and writes observations for each student in his or her progress notebook which must be given to the student.

An important part of the teaching practice period is the writing of the teaching report under the supervision of one of the training centre professors. Several comments on these reports are in order. Firstly, the structure presents all of the elements of a research paper (introduction, sections for topics of research and opinion, conclusion, annexes and bibliography). Secondly, the focus of the report is not so much a reflection on the practical activity being carried out in order to improve performance, but rather on some particular problem area in one's school performance.

At the end of the second year of training the student undergoes three types of evaluation. The first evaluation deals with teaching practice. This is divided into two parts: one is an assessment of the progress notebook and the other is carried out by a commission, the members of which are an inspector, the practicum tutor and the student's own tutor at the training centre.

A fundamental aspect of this part of the evaluation is the "rapport de stage" in which specific aspects of the student's competence ${ }^{6}$ are scrutinised and the commission presents a competence report and gives a grade. The second type focuses on the student's practicum report, which must be defended before a jury and is deposited in the training centre. Here too, the student receives a grade for his or her report (very poor, poor, pass, and very satisfactory. The pass mark, for example, is 14 points out of a maximum of 20). The written criteria for evaluation of the student's teaching practice report, which appear in the certificate awarded by the jury, are the following: writing (presentation and expression), dossier (analysis, arguments, teaching practice, research and creativity) and defence (fluency of expression, active listening capacity, and the resources used). For the first and third criteria the maximum grade is 5 out of 10 and at the end of the evaluation process all three grades are added. The certificate also includes a section in which the jury may write a summary of their overall impression. They usually include laudatory comments.

The third element for evaluation is the so-called continuous assessment of disciplines studied during the first and second years and which are also given a final grade. If the student is successful in all three evaluations, which is usually the case, then s/he receives the Professional Diploma which qualifies her/him to enter the teaching profession where s/he is assured of secure employment in the private education sector. In France there is a demand for teachers in private schools. 


\section{The Contribution of Italy}

The private sector in this country at the various levels of teaching is much smaller than in France or Spain. There are approximately 55 public universities and only four private ones: Instituto Suor Orsole Benimcasa in Naples, the Catholic University of the Sacro Cuore, which has five centres (Milan, Brescia, Piacenza-Cremona, Rome and Campobasso), the LUMSA in Roma and the Libera Universitá di Bolzano, which has a special statute. These universities provide Primary Teacher training, and only in Bolzano and Napoli ${ }^{7}$ do we find the SSIS (Schools of Specialization for Secondary Teaching) which trains secondary school teachers. A detailed examination of the functioning of these four institutions has allowed us to observe their singularities.

To begin with, it is useful to point out that the old Teacher Training Institutes were substituted by the Faculties of Education Science, where the "Corso di Laurea" in Primary Education Sciences is offered, with the object of preparing future pre-school and primary teachers. Also, for the first time, secondary school teachers are now being trained. Until the academic year 1999/2000 these teachers practised their profession without any specific teaching qualification. The enactment of Law n. 341 of November 1990 began a period of great hopes which became a reality with the Murst Decree of 1998 by permitting the appearance of the Specialization Schools for Secondary Education (SSIS), which are independent centres at university level. The recent incorporation of European university policy (academic year 1999-2000) to the Italian system is making a difference to the pace of project design and experiences related to teaching plans of the teaching staff, more significant in the public institutions than in the private ones.

Nevertheless, there is a greater similarity in the application of DM 509 of the 3rd November 1999 which determines the university training credits as units of learning (in which one credit is the equivalent of 25 hours of class). Despite the progressive implantation of university reform, the Ministerial Decree of reference clarifies both the end of the former academic system and the official recognition of qualifications obtained before the beginning of the reform in the academic year 2001-02.

From the point of view of institutional development, it is clear that the four universities of the private sub-system provide training for primary school teaching and only in Bolzano do we find the SSIS for the training of secondary school teachers.

Naples, capital of Campania, is one of the cities with the widest offer of university education, both in number (five universities which provide higher education. ${ }^{8}$ ), and in quality. Four of these are state-run and one is private. The Instituto Suor Osole Benincasa is the only private university in southern Italy. This is a monastic complex which provides a broad educational programme from the earliest stages of education up to university level. Regarding university teaching, this institution has focused principally on the present Facultá di Scienze della Formazione Primaria, the old Faculty of Primary School Teaching (founded in 1895) and on the recent Faculty of Jurisprudence (academic year 1998-99), and also offers qualifications in foreign languages, history of art or the conservation of items of cultural interest. At other educational levels, pre-school and primary school education is also provided as well as linguistics and art at highschool level. 
The Libera Università Marìa SS. Assunta (LUMSA) was originally the University Institute founded under the RD of 26th October 1939, No 1760, which provides legal cover for the academic recognition of the university's qualifications. In this regard, the Ministerio dell'Instruzione dell'Università e della Recerca Cientifica is the institution responsible for control and supervision. La Facoltà de Scienze della Formazione, originally the Faculty of Primary Teacher Training, dates from 1996. Its objective is to offer a wide range of training programmes specifically adapted to the demands created by current cultural processes as well as social changes and the new realities of the workplace.

The Libera Università di Bolzano was created in 1997 and it cannot be unequivocally stated that it belongs to the private sector. It should be pointed out that it enjoys a special statute which is mentioned in the Murst Decree of 1998.

Concerning curricular premises, it is interesting to note that the education model of curriculum organisation is the same in the private universities as in the public universities. During initial primary teacher training the simultaneous formula is applied, which means that over the four-year course, or Laurea, general education and professional training, both theoretical and practical, are provided. This academic structure is at present undergoing change as a consequence of the application of the European model for higher education and tends towards the formula of $3+2$ (the primary degree and the postgraduate specialist qualification). The Murst decree defines the concept of the training credit according to the ECTS system ${ }^{9}$. However, in the private universities the old formulae, in place for many years, still prevail, even though the new terminology of university education credit is used.

Within the private education system, it should be emphasised that the Universidad Católica del Sacro Cuore, unlike the other private universities, is noted for its long established social education programme. It was founded in 1921 and received State recognition and legal status in 1924. The Teacher Training Institute of Milan was founded in 1936 and in 1996 became the Faculty of Education Science under Law 341 of the 17th November 1990 (Riforma l'ordenamento didattico universitario). Under this law the Teacher Training Schools and Institutes, which did not have university status, were replaced by university-level training centres, thus incorporating the new pedagogical trend for primary school teacher education. In Brescia, the Facoltà di Magisterio opened in 1965. In Brescia and in Milan the "Corso di Laurea en Scienze della formazione primaria" is provided, but not in the other centres. Similarly, at the Institute of Naples the changes brought in by the Murst Decree are being carried out but with delays. In the academic year 2004-2005, the first year of the new "Laurea" in teacher education had not yet been started, as the new regulations require.

Concerning the cultural component and the pedagogical dimension implicit in the Italian training system, the curriculum model is similar for public and private universities. In the latter the similarity is also noteworthy. A brief examination of the curriculum shows general, overall areas of study, including teaching methodology, pedagogy, psychology, socio-anthropology, health and hygiene studies, linguistics and literature, mathematics and computer science, physical sciences and modern languages. General teaching methodology is introduced in the first two years and methodology for specific 
disciplines begins in the third year. However, throughout the entire course students take subjects such as history, English, education law, computer science, etc. The curriculum provides students with a grounding in encyclopaedic knowledge and culture and therefore clearly leans towards the disciplines.

An important question, although formal, which invites a more integral reflection in relation to the professional formation of the teacher, is the increase in the academic requirements for entry to the teacher training course (the Curso de laurea en Ciencias de la Formación Primaria). In accordance with regulation DM 26-5-98) the formalization of this qualification requires the student to have the diploma of instruzione secondaria superiore di durata quinquenale ${ }^{10}$ and to have passed an entrance examination. ${ }^{11}$

These are four-year degree courses, divided into two periods of two years. During the first two years the students are taught general subjects and in the second, trainee teachers may choose either pre-school training or primary training. The above-mentioned decree requires that in each academic year there should be 60 credits, distributed among theory seminars, teaching laboratories and tirocinio (practicum). At the end of the training course, students take the Laurea examination, which is State recognised and qualifies them to teach. The theory seminars must include a range of disciplines of diverse scientific areas allowing students to acquire knowledge and competence in general education as well as teaching skills. The laboratories are areas for reflection where students and professors analyse the various activities which may be used to transmit knowledge.

The Laurea course in Education Sciences for Primary Teaching contains 240 credits to be acquired over four years, each year having two semesters. Below is a table showing the distribution in time of the teaching programme.

\begin{tabular}{|c|c|c|c|c|c|c|}
\hline & & Seminars & $\begin{array}{l}\text { Laboratory } \\
\text { Credits }\end{array}$ & $\begin{array}{l}\text { Tirocinio } \\
\text { (Oractucyn) }\end{array}$ & $\begin{array}{l}\text { R. } \\
\text { Thesis }\end{array}$ & $\begin{array}{l}\text { Total } \\
\text { Credits }\end{array}$ \\
\hline First & 1st Semester & $6(21 \mathrm{cred})$ & 3 & 6 & & 30 \\
\hline Year & 2nd Semester & $6(21 \mathrm{cred})$ & 3 & 6 & & 30 \\
\hline Second & 1st Semester & $6(21 \mathrm{cred})$ & 3 & 6 & & 30 \\
\hline Year & 2nd Semester. & $6(21 \mathrm{cred})$ & 3 & 6 & & 30 \\
\hline Third & 1st Semester. & $6(21 \mathrm{cred})$ & 3 & 6 & & 30 \\
\hline Year & 2nd Semester. & 4 (14 cred) & 3 & 6 & 7 & 30 \\
\hline Fourth & 1st Semester. & 4 (14 cred) & 3 & 6 & 7 & 30 \\
\hline Year & 2nd Semester. & 4 (14 cred) & 3 & 6 & 7 & 30 \\
\hline
\end{tabular}

As we have already mentioned, the teaching plan includes a combination of general academic disciplines aimed at providing a general cultural background and specialist subjects whose aim is to prepare future primary or pre-school teachers. 
Nonetheless, there are some slight differences in curriculum design of the private sub-system regarding initial training. Proof of this is the fact that there is a larger cultural component in the first two years of the training course provided at the Universitá del Sacro Cuore than at the Naples Institute. However, this cultural dimension is being replaced, both in third year and in fourth, by an approach which is more focused on the teaching methodology of the areas of knowledge taught than on the material itself. It should be pointed out that there is great similarity between the instrumental areas of the second two-year period of the course of pre-school and elementary teacher training. The same is the case with the laboratories and the disciplines.

Special mention should be made of the practical training given to primary school teachers because of the importance over recent years which the tirocinio has acquired. This element, which has become an essential referent in the teacher training system, is conceived of as a place of integration of theoretical and operative competences. In structural terms, it comes into place at the end of the first year and should not total more than $20 \%$ of the credits for the entire course. In general terms, this is a training experience which is carefully programmed and covers observation, study, increasing responsibility, reflection and verification. It requires a balanced mix of several elements: formative, operative and reflective (Chiapetta, 2002).

Training component:

Group preparation sessions under the guidance of a supervisor

Operative component:

Theoretical knowledge versus direct experience in the school

Reflective component:

Reflection, synthesis and transmission to the group of the knowledge acquired.

One of the most important contributions of the Italian model is the political will to unite the theoretical foundations of education with their practical applications. This allows a deeper knowledge of the structure and organisation of teaching personnel according to their role in the institution: professor, supervisor, lecturer. The supervisor is a key figure in the process of practical training and acts as intermediary between the University and the school. ${ }^{12}$

As we have seen, in the preparation of future teaching professionals, the tirocinio is a fundamental component of the course in that it favours critical, mature reflection of the practical experience acquired, while providing knowledge of the stages in the curriculum as pupils progress over time, and also of the pedagogical "laboratory".

The organisation of the practicum into three clearly defined phases is evidence of the intention to integrate the basics of educational action into a compact structure. The sequence commences with the preparatory phase which includes a training component. This is followed by direct classroom experience in which the operative dimension of the process is activated and, finally, the phase of reflection which requires a higher level of intellectual ability and discourse skill. 


\section{The Portuguese Case}

Portuguese higher education is divided into two sub-systems: university teaching and higher, non-university teaching, referred to as polytechnic. Both university and polytechnic teaching are carried out in public, private and cooperative institutions. Private higher education institutions have expanded and developed rapidly in Portugal since the last decades of the twentieth century. Article 54 of the Law for the Bases of the Education System of 1986 gives State recognition to private education as a concrete expression of the freedom to learn and the right of the family to choose the type of education they wish for their children. The regulations guarantee the right to create private schools. These institutions must be officially recognised in accordance with the Statute of Private and Cooperative Higher Education (Estatuto do Ensino Superior Particular e Cooperativo $)^{13}$. These centres carry out their educational work according to the general directives from the Ministry of Education which recognises their degrees and diplomas and authorises the inclusion of these centres in the national network of higher education.

Nevertheless, each of these private schools enjoys full autonomy in educational, scientific and cultural matters. They organise their schools as they see fit and are free to offer education programmes in line with their principles.

In terms of institutions, it is the Escola Superior de Educaçao which also provides teacher training in the private model. In other words, the name of the institution is the same as that which applies to the public institutions which are integrated, in this case, in the Polytechnic Institutes. The Piaget Institute ${ }^{14}$ is a cooperative educational establishment founded in 1979 whose main objectives are to provide quality teaching, generate knowledge and instil fundamental human values, prepare students to become effective professionals and to contribute to their personal and intellectual formation. This institute ${ }^{15}$ trains educators for pre-school and primary levels, according to a particular philosophy, that is to say, the establishment of Piaget Institutes in Portugal forms part of the development plan for the more disadvantaged regions of the country and responds to the most urgent need for trained teachers.

The Statutes of the private institutions must be approved by the Ministry of Science and Higher Education. The proposal presented to the Ministry must set out the objectives of the centre, its organisational and administrative structure, enrolment regulations and the rights and duties of the teaching staff.

With regard to curriculum design, the syllabus for the training of teachers for the pre-school stage was approved by Despacho no 379/2002 of the 8th April. According to this syllabus, the number of weeks for each school year, not including weeks devoted to evaluation, may not be fewer than 30 and for each semester no fewer than 15 . The maximum number of students admitted each year is 60, making a total of 240 for the four years. A student who has passed all subjects, or "curricular units", receives a Degree in Primary Education Teaching.

The Degree in Basic Education consists of two cycles. The first is regulated by Despacho $n^{\circ} 382 / 2002$ of 8th April, establishing the number of weeks per school year at no fewer than 30 . The maximum number of students per level each year is 75 , the total maximum for Basic Education being 300. Students who pass the curricular units set and approved by the Ministry are granted a certificate of the first stage of Basic Education. 
The second stage is similar to the first except for mathematics, natural sciences, technology, physical education and music education.

Regarding the education provided at the private schools, independently of the stage (pre-school, basic or upper secondary), there is a common denominator. Education covers scientific and pedagogic aspects as well as teaching practice, presenting a balance between practice and theory, thus allowing educators to meet today's increasing social and scientific demands.

Portuguese education policy is moving towards a greater social recognition of the teaching profession by means of providing a more solid cultural foundation along with technical and scientific knowledge, covering a wide area of knowledge focused on the development of children, on pedagogical trends and models and on developing competence.

The entire process is aimed at preparing technically competent professionals. Taking as a starting point the new perspectives and innovative pedagogical practices, the future educator is trained to be an important and active figure in the development and socialization of children. The educator is intended to be a specialist capable of producing and implementing integrated educational programmes, and of holding discussions with various professionals in the field of education.

Practical experience in the Portuguese education system is an important and compulsory element. Teacher training involves collaboration between the training institution and the school where teaching practice takes place.

As with the practicum model for public centres, the private centres are also based on the investigation-action model which produces a reflective teacher who, in turn, will encourage reflection in the pupil.

The "reflective practitioner" is that teacher who is sensitive to new situations that arise in the area of his/her work and, as fruit of his/her reflection, is capable of objectifying, analysing and integrating these into his/her daily work. The "reflective practitioner" distances him/herself from the simple practitioner and concurs with those teachers who "practice educational innovation ${ }^{16}$.

This is a type of training that we might refer to as the alternation type, combining the theory taught at the training centre with practical, school-based experience. Practical experience is provided to students during three years of their four-year course. This type might also be called the school-based plan. In this case, the teacher at the school where the student gains his/her classroom experience is also involved and works together with the trainee and the training centre tutor.

From the second year on, the students begin their practical training at schools. Under the guidance of the teacher-tutor, the student teachers observe and study the school and its environment. They spend two days a week at the school and three at the training centre. Throughout the course they carry out innovations, experiences and discussions on problems that may arise and deal with the programme set out in the discipline of "Teaching Practice". In the third year the number of teaching practice hours is increased and the trainee teacher takes on greater responsibility in the classroom. In the final year the student spends three days at the university training centre and three on teaching practice. 
The following table sets out the programme of subjects studied and the time devoted to practical training.

\begin{tabular}{|c|c|c|c|}
\hline & INFANT SCHOOL & FIRST CYCLE & SECOND CYCLE \\
\hline $\begin{array}{l}\text { First } \\
\text { Year }\end{array}$ & $\begin{array}{l}\text { - Seminars I } \\
\text { - Anthropological Field } \\
\text { Work and Sociographic } \\
\text { Methods }\end{array}$ & $\begin{array}{l}\text { - Seminars I } \\
\text { - Anthropological Field } \\
\text { Work and Sociographic } \\
\text { Methods }\end{array}$ & $\begin{array}{l}\text { - Teaching Practice: } \\
\text { Anthropological Field } \\
\text { Work }\end{array}$ \\
\hline $\begin{array}{l}\text { Second } \\
\text { Year }\end{array}$ & $\begin{array}{l}\text { - Seminars II } \\
\text { - Teaching Practice } \\
\text { ( Practicum and } \\
\text { "Micro-Ensino") }\end{array}$ & $\begin{array}{l}\text { - Seminars II } \\
\text { - Teaching Practice } \\
\text { ( Practicum and } \\
\text { "Micro-Ensino") }\end{array}$ & $\begin{array}{l}\text { - Teaching Practice } \\
\text { "Micro-Ensino" } \\
\text { Laboratory }\end{array}$ \\
\hline $\begin{array}{l}\text { Third } \\
\text { Year }\end{array}$ & $\begin{array}{l}\text { - Seminars III and } \\
\text { Final Report } \\
\text { - Teaching Practice } \\
\text { (Practicum) }\end{array}$ & $\begin{array}{l}\text { - Seminars III and } \\
\text { Final Report } \\
\text { - Teaching Practice } \\
\text { (Practicum) }\end{array}$ & $\begin{array}{l}\text { - Teaching Practice and } \\
\text { Laboratory Practice }\end{array}$ \\
\hline $\begin{array}{l}\text { Fourth } \\
\text { Year }\end{array}$ & $\begin{array}{l}\text { - Seminars IV and } \\
\text { Final Report } \\
\text { - Teaching Practice } \\
\text { (Socio-educational } \\
\text { Intervention Project) }\end{array}$ & $\begin{array}{l}\text { - Seminars IV and } \\
\text { Final Report } \\
\text { - Teaching Practice } \\
\text { (Socio-educational } \\
\text { Intervention Project) }\end{array}$ & $\begin{array}{l}\text { - Seminars and } \\
\text { Final Report } \\
\text { - Teaching Practice }\end{array}$ \\
\hline
\end{tabular}

As we can see in the above table, during the first year and the first cycle, the students receive theoretical classes (Seminars I) at their own centre. These sessions prepare them for their practicums which will take place the following year. They also carry out a study of their city of residence as part of the subject entitled "Trabalho de Campo Antropológico" and will later present their findings to their tutor at the training centre. During the remaining years of training, the practical teaching subjects form part of the so-called seminars. In the primary school classroom the students observe the work of the class teachers, take over some teaching responsibility and have the opportunity of contrasting theory with the demands of hands-on practical teaching. Practical teaching is always supervised by a tutor teacher.

Throughout the entire process the school-based practice is supervised by the teacher-tutor. The trainee teacher's practical formation is influenced by the example of the class teacher's methods and responses to everyday situations that arise in the classroom. This influence may go beyond the practical and lead to a process of abstraction of theoretical ideas and their practical application. It is by means of educational conversations with the teacher-tutor that the trainee acquires the resources to establish his/her didactic paradigm. 
Assessment of practical training is carried out over the four years of the course, special attention being devoted to this aspect from the second year on because this is when the students begin their school-based training practice. At the end of this second year, and again at the end of their third year, students are expected to present to their university training centre tutor a written reflection on and synthesis of their practical experience. This document is known as "Portefolio". At the end of their fourth and final year, as well as the "portefolio", students also present a Final Report, which must be the product of research activity on pedagogical topics chosen from the syllabus. This written assignment is a central element for assessment of the practicums.

\section{The Spanish Model}

Legislation since 1990 has established the regulations by which the Spanish education system is organised and the general guidelines for the education of teachers. The following are the laws which underpin the current system: Basic Law 1/1990, of the 3rd October, Basic Act on General Organisation of the Education System, Basic Law 10/2002, of 23rd December, of Quality of Education (the former a social democratic law and the latter conservative), and also Royal Decree 1440/1991 of the 30th August,.

Spain does not have a historical tradition of private universities, with the exception of Deusto University and the Pontifical University of Salamanca. This is due to the fact that nineteenth century liberalism opted for the public model of higher education. However, throughout the Franco period, private centres for the training of primary school teachers began to appear. These were linked to the Falangist Movement or to the Catholic Church and later attached to the universities (Complutense Madrid, Valladolid, Valencia or Seville)

The LRU (Basic Act of University Reform ) of 1983 opened the door to the possible establishment of private universities in Spain, but only if the Government published a decree setting out the institutional, financial and academic conditions and requirements. This decree was published in 1991 and since then the creation of private universities has become widespread. The private universities which at present offer teacher training in accordance with the criteria established for the public universities are the following: the Pontifical University of Salamanca (Luis Vives Primary Teacher Training School, the Ramón Llul University, the University of Vic, the Catholic University of Valencia, "Saint Vincent the Martyr", the University of Mondragón and the International University of Catalonia. However, these institutions are few in comparison to the number of public institutions devoted to the education of teachers.

In order to gain admittance to teacher training studies at private universities or centres of higher education, students need to meet the same entry requirements as for the official system. ${ }^{17}$ However, in the case of private universities, when the demand for places exceeds the number of places available, there is an added filter in the form of an interview or a test, the object of which is to establish that the candidates' ideology is in line with that of the institution.

The practical training consists of 32 credits spread over the second and third years of study, which is little more than $16.5 \%$ of the total for the education provided at these 
centres over the three year study period which leads to the qualification of primary school teacher. The specialities offered are the following: pre-school, primary, music, special needs education, physical education and foreign languages. The education the future teachers receive is mainly cultural and encyclopaedic, centred on the disciplines, and little attention is paid to the practical aspects of teacher training. Thus, the Spanish model of teacher training produces, not general primary teachers but rather, specialists.

In general terms, organisation of the period of practical experience in the schools, in line with the public model, is carried out simultaneously with studies of the disciplines, teaching techniques and pedagogy at the training centre.

Regarding the content of the practical aspect of teacher training, the guidelines stress active and participative methods by means of systematic observation and dialogue with the head teacher and the class teacher at the primary school. The students collaborate with the teachers in the everyday tasks at the school. They must be aware of the General Class Programme, of any adaptations, significant or not, of the educational programmes and the special projects. They also analyse the teaching materials used and participate fully in the teaching/learning process.

The schools where teaching practice takes place are centres for pre-school and primary education, referred to as "colegios" and may be either private or State funded. There are formal agreements for collaboration between institutions of ideological affinity. At the beginning of the academic year, the public teacher training centres publish lists of possible schools (or colegios) where trainee teachers may carry out their practical training, depending on preference and availability of places. Prior to starting the practical period, the Commission for Teaching Practice contacts these schools to check availability and confirm the number of places which will be required. Students are placed on a list and placements assigned according to academic results of the previous year and student preference. Students may also request placement at a school which is not on the centre's list of teaching practice schools, an option exercised more and more frequently by students.'

The practical training period finishes with the presentation (but not the defence) of a written assignment set by the university in which the student describes, analyses and discusses observation and practical classroom tasks carried out at the school. This assignment is referred to as the Teaching Practice Report. This is an original and personal document.

The student writes his/her own account of all she/he has learned and observed during the practical training at school. There are two parts:

a) the primary school speciality which the student has chosen. An account should be given of how the specialist class teacher works with the pupils. The student teacher collects data on collaboration with other staff members, on how the cross subjects and attention to diversity among the pupils are approached, the form, style and method of assessment of the various subjects and the development of the teaching/learning process.

b) description of tasks carried out, trainee's performance in the classroom and overall assessment of his/her own work. The report must contain a description of the group of pupils with whom s/he has worked, drawing particular attention to the planning 
and actual teaching of two sessions given by the student. These lesson plans should include objectives, content, strategies, methodology, resources, timing and assessment. The student also reflects and comments on and assesses his/her work.

Formal rules for the writing of this report set out the number of pages, font, margins as well as the structure and the information which must appear on the front page. The report must be signed (authorised) by the student's teacher-tutor.

\section{Comparison Process: Similarities, Differences and Interpretation}

Our objective here is to present some reflections in relation to the three axes of the discursive sequence set out at the beginning of the present article which include key questions such as the framework of regulations, development of institutions and the academic aspect. We have opted to analyse the similarities and differences among the teacher training paradigms of the countries represented in this study. Each case has been approached from a comparative point of view and this has allowed us to combine information, while attempting in all cases not to lose the cultural, social and ideological referents that underlie training policies. This will be discussed in the next section.

\section{Comparison of Regulatory Framework}

Based on these premises and in terms of existing regulations, it can be seen that the legal bases on which the education and training of future teachers rests are the same as those for the public model, apart from some specific points. In the case of France with La Loi d'Orientation sur l'Éducation, 1989 (with a decree for the private model of 1992). In Italy there is Law 341/ 1990 concerning the reform of the University teaching organisation, which led to the disappearance of non-university teacher training centres (Instituto Magistrale y Scuola Magistrale). In Spain, change came about with the LOGSE of 1990 (Basic Law of the General Organisation of the Education System) and Royal Decree 1440/1991 of the 30th August which establishes the University Qualification of Primary School Teacher, valid throughout all parts of the country. Portugal introduced the changes by means of the Education Act of 1986 (Lei de bases do sistema educativo).

We would emphasise that the changes in the legislative framework in the four countries came about at relatively the same time. Portugal was the first country to introduce change with the Education Act of 1986; France, Spain and Italy began the reform process in the 1990s. Does this mean that the penultimate decade of the last century was a decisive period in western societies for the reform of educational systems? We will attempt to answer this question below.

J. Barroso (2005) distinguished several different regulation models. "Supranational regulation" comes from the international trends. Politicians make reference to it in order to enforce and to legitimate changes to be adopted by educational institutions, in other words, "school self-management" (J. Barroso, 2005, p. 157). "National regulation" (expressed in coordination and control) is a kind of "alliance" between the State 
and teachers and excludes pupils' parents and the community. It combines bureauocracy and professionalisation. "Microregulation" is the process of coordination of the various professionals involved in education, is the relationship between administrators and "the administered" (the vertical perspective) and between those who occupy positions of interdependence (the horizontal perspective), schools, territories, municipalities, etc.). "Metaregulation" is not only a question of difference between two options of a government model of education: on the one hand a centralised, planned and hierarchical administration and, on the other, the decentralised, concurrent and autonomous model. There are other alternatives, for example, independent reflective self-organisation, involving complex relationships of reciprocal interdependence (Jessop, 2003) (Y. Duterecq, 2005, p. 167), which lead to the "governance of governance" or metagovernance. The various regulations formulated previously can be applied to the organisation and functioning of of private teacher training centres in the countries studied. Some of these regulations have greater force: supranational (owing to the European Union and its efforts at convergence), local-territorial (because of increasing decentralization) and the metaregulation coming from the ever-increasing and influential application of market models to the administrative and academic organization of training centres. Nonetheless, since our interest is in private centres connected to the Catholic Church, we must also take into account the additional rules and criteria imposed by the ecclesiastical hierarchy, which might be referred to as "ideological regulation".

\section{Institutional Comparison}

From the institutional point of view, it is important to point out that in some countries, such as France and Italy, there is a direct relationship between schooling and teacher education in that the presence of the private sector is limited both in terms of the first variable and of the second, with approximately $15 \%$ of pupils enrolled in private primary schools. In Italy there are only $8 \%$. This proportion of pupil numbers in private schools is, in general terms, similar to the proportion of private institutions within the educational system. On the other hand, in Spain this correlation does not exist, given that schooling at privately run primary schools is approximately $33 \%$ of the total, while the percentage of private teacher education centres is considerably lower in comparison to the strong presence of public institutions throughout the country. A further point is that the percentage of private centres of primary education is $24 \%$ of the total, which indicates that private schools are bigger. This is due to the fact that they are mainly situated in urban areas. Nor does Portugal follow the above-mentioned patterns, given that approximately $10 \%$ of primary school pupils attend private schools, while $34 \%$ of the total number of teacher training centres are private institutions.

From another perspective, attention could be drawn to the institutional profile of the training centres. In France the CFPP (Centres de Formation Pédagogiques Privés), which have academic and administrative connections with the universities, are legally recognised. In Italy, teacher education, both public and private, is fully incorporated in the university structures by means of the Corso di Laurea. In Spain the model is somewhat ambiguous given that some universities are fully integrated into the system while others maintain the old-style professional schools. The situation in Portugal is similar to 
that of France: the Escolas Superiores de Educaçao are the private sector equivalent of the Escolas Superiores de Educaçao which depend on the public Polytecnhic Institutes (Institutos Politécnicos). What can be affirmed is that in all four countries standards of teacher education have risen considerably. Entry requirements are more stringent and so are the content and organisation of the curriculum offered to future teachers. Furthermore, these centres are now either centres of higher education or universities.

From an institutional point of view, comparison can be made of similarities and differences among these four countries. While in Spain and Italy there are few private teacher training institutions, in France and Portugal there is a relatively significant number of private training centres administered in accordance with Catholic principles. The principle of laicism in French schools is currently at a "crossroads". We will deal with this subject later.

\section{Academic Comparison}

Finally, regarding the academic framework, some considerations can be discussed. One academic element for comparison is the general model of training which is offered in the four countries studied. We have observed both similarities and differences. With regard to the similarities, all four countries have the clear objectives of producing effective, professional classroom teachers. Similarities can also be seen in the desire to produce well-designed curricula and course content, as well as the fact that training courses are now either university or higher education level. The second similarity of the model requires some additional explanation in that we are not referring to the method of curricular organisation (we will draw attention to this below), but to the inclusion in the training programme of a wide variety of cultural knowledge (history, literature, foreign languages, philosophy, sociology, etc.), pedagogical knowledge (teaching theory and practice, research techniques, history of education, school organisation, educational polity, etc.) and practical experience (monitoring, tutorials, preparation of the written teaching practice report, etc). All of this shows that the training systems of the four countries clearly belong to an encyclopaedic tradition (as opposed to humanist and naturalist), which is largely defended on grounds of universality, rationality and utility. These criteria are characteristic of the French system and, to a lesser degree, of countries such as Italy, Spain and Portugal (Vonk, 2000:70). The traditional influence which France has had on Mediterranean countries can be seen quite clearly.

The differences among the four countries have to do with the length of the training period, the system of academic organisation and the overall nature of the training (general or specialised). In France, students undergo a five-year period of education and training: three years of general university studies and a further two in CFPP. In Italy and Portugal, future teachers undertake four years of university studies and in Spain only three, the objective being to provide students with professional preparation. However, this is currently under debate and arguments in favour of a four-year training course are based on a comparative European perspective. It is thought that Spain should take advantage of the beginnings of the construction of the European model of higher education. Concerning the length of the period of study and the contents of the training course and bearing in mind the study of curricula which we presented above, 
we examined content organisation in four training categories: culture, the disciplines, pedagogy and the professional aspect. In the case of France, the first is independent of the other three categories and involves a three-year university degree, while in Italy, Portugal and Spain, subjects of general culture are offered simultaneously with subjects of the other three categories. Disciplines in the French model are taught in the first year by way of preparation for the concours, or competitive examinations, and again in the second year of practical training, while in the other three countries, this category is taught simultaneously with the other three. This is also the case with pedagogical training and the practicum. The French model, although not strictly of university level, is higher education, and defines with greater institutional clarity the different periods of overall continuous education, internally simultaneous over the two years devoted specifically to teacher training. This means that France, relatively speaking, broke with the traditional model, while Spain, Italy and Portugal have carried out institutional changes but without breaking with the traditional mould. Spain, Italy and Portugal continue to provide future teachers with cultural knowledge and disciplinary education while simultaneously providing pedagogical and professional training.

Although it is not our intention to attempt to assess the pedagogical suitability of these training models, we believe the debate should centre on the cultural, historical and ideological reasons behind governments' choice of training systems, and also on the co-existence of the simultaneous and consecutive models in countries such as England, which is an indication that autonomy of the institutions of higher education implies less state responsibility. (Ferrer, Naya, Valle, 2004:175).

Regarding the third difference, the comprehensive nature of teacher training, we have found that in France and Italy the curricular models are designed to train the general teacher, while in Spain and Portugal, training is focused on a combined model of training for teachers: the training of specialists, (music, foreign languages, physical education, etc) and generalists (infant or primary).

Concerning the comparison of practical training, there are also similarities and differences. The similarities are to be found in the training model (usually simultaneous), in content and in the requirements for practicum (observation and responsibility on the one hand and, on the other, the requirement that students present a Professional Report which reflects the entire process of practical training. A number of differences are to be found. In the first place, the length of time devoted to the education and training of teachers varies in the different countries. France is the only country where trainee teachers undergo practical training after passing an entry test to professional practice. Secondly, there are differences in the evaluation of practical training. In Spain, Italy and Portugal this is carried out by the teacher-tutor and reflects both the performance of the student teacher and a report by the professional tutor, whereas in France the "rapport de stage" is assessed and, in addition, a commission formed by the teacher-tutor, the training-centre tutor, and an inspector. However, the final assessment is based mainly on the student's teaching practice diary. Regarding this difference, we should point out that in Italy practical training is about $20 \%$ of the entire teacher education course; in France too, students spend approximately 20\% of their two year training period in practicums, which shows that the widespread French professional 
model for teacher training does not appear to be determined exclusively by practical training. In the case of Portugal, considerable importance is given to the practical part of general teacher education, as can be seen by the proportion of time allotted to this aspect. In Spain, despite the combined model of training for general teachers and specialists, the solid grounding provided by practical training is not a significant element in the overall approach to teacher training.

\section{Towards an Interpretation}

On the other hand, and starting from the analysis of the elements which have been compared, our aim is to make an explanation of each of them based on reasoning categories that will give us the keys for understanding the real dimensions of teacher training.

In this section we will further discuss the comparative elements which we have presented in the above paragraphs. We intend to approach this explanation from four categories of argument: the cultural and mental traditions among which the presence of faith and doctrine play an important role in social and school practices; the State administration organisation models and their systems of legitimization; the interpretation of the training curriculum in terms of governance and discipline and, fourthly, the European perspective of training.

The interpretation of laicism provided by Fernando Savater is of great interest to us in its application to the academic models of teacher training. His concept is that political and civil aspects are recognised as autonomous with regard to the religious one, but also that the contrary is true. The political and civil aspects do not interfere in religious matters but neither should the Church and doctrine be involved in the control of the public system. From this perspective, only in France can one speak of a lay training system and the resulting autonomy of curriculum of the CFPP. The lay tradition of the French education system goes back to the reforms of J. Ferry at the end of the nineteenth century. This is not the case in Spain and Portugal, which do not have a lay system given the Church-State agreements (in the case of Spain, signed in January 1979) and there remains a doctrinal presence in the curricular design for the training of teachers.

The curriculum (in its broadest sense), as a modern invention, implies forms of knowledge whose functions consist of regulating and disciplining the individual. It is interpreted, therefore, as a system of governance and discipline (Popkewitz, 2003, p. 156). It is a set of methods and strategies which include principles for action. The curriculum is expressed through cultural and social practices.

This approach to teacher training means that the training is understood as control, as power. This governance and this power are apparent both in cultural contents and in psycho-pedagogic components, which is where the prescriptive nature of curriculum design is most striking.

The French training model offers more disciplinary contents and it is this component of the curriculum which leads to greater professionalism in teachers. In terms of training, intercultural education, sex differences, human rights, new technologies, etc. it might be interpreted as part of an effort to correct inequalities in society in this framework of governance (Heyning, 2003). Nonetheless, we must not forget that we 
are referring to a period of transition, of adjustment of regulations related to practical teacher training (the 1980s and 1990s) when in England and Wales the Act of 1988 was passed. This Act was inspired by neoconservative principles and therefore reflects the concern for maximum results in the educational system. In France and in Spain Social Democratic parties were in power at this time and in Italy there was a CentreLeft coalition from 1996 to 2001 . This is relevant in that it lessened the effect of the influence of market economy principles on education, on competition among education centres and control and the standardizing trend associated with apparent decentralization.

In this reconstruction of the convergences and divergences in the teacher training paradigms in the countries analysed, we cannot overlook the fact that if the configuration of these training models has been for many years exclusively the responsibility of the State, which has contributed to reinforcing national sovereignty, in recent years the addition of the European dimension to education policies is favouring the construction of supranational systems which share common guidelines on education in general and teacher training in particular.

Italy and France have the greatest advantage in terms of adaptation to the European Area. Their commitment is outstanding not only concerning the introduction of two cycles in the higher education structure but also referring to the introduction of the European credits transfer system and the use of the so-called diploma supplement which was made compulsory in Italy in 2004-2005, although but is still just a recommendation in France.

\section{Final Assessment}

The study of the private model of initial teacher training has centred on countries which share certain, cultural, social or economic similarities. This has been our starting point in considering general issues regarding the parameters we have analysed.

Regarding the management of public-private training, we would point out that the private sub-system of schooling and teacher training in the countries studied does not possess a specific political and administrative set of regulations, but rather regulation of the public system is, on the whole, applied to the private model, although with certain differences. This indicates that there is one system, not two, but with two lines of internal development.

The institutional frameworks are clearly different both in name and in the spaces and resources employed in the training processes. However, their organisation and functioning follows the public model, although greater dynamism and contact with new developments can be observed in private centres.

Diversity is the most outstanding characteristic in the models of initial teacher training in the private sub-system and in relation to the practical component, not only in terms of regulation and of institutional developments but also in the organization of academic and practical training. 
The increase of private management in the educational processes is closely linked to the distribution of responsibilities in the teaching area. At this point in our reflection, an examination of each one of the systems studied has provided us with information to make comparisons and even generalizations related to the delegation of powers in the countries studied. The current reforms show a tendency towards decentralization at both State and regional level. At institutional level and in terms of university management there is a certain homogeneity of recognised responsibilities within the framework of higher education in all four countries. The divergences of focus of autonomy are to be found at lower educational levels, where centralised policy is more evident. This is characteristic of the French educational system, although in recent years there has been a tendency towards decentralization. Decentralization of management is also the case with the Spanish and Italian educational models.

Finally, we have focused our attention on how far the training models have progressed towards the new university policy. There are differences in the rate at which the main axes of the European Higher Education Area are being adopted. Portugal offers good proof of this in that some of the methodological formulations, such as the credit system, have not yet been fully incorporated. Regarding legislation, Law 1/2003 for development and quality in higher education has been an impulse towards installing the new curriculum organisation and Portugal is now moving towards a credit system in line with the ECTS by virtue of the Decree Law 173/80 of the 29th March, 1980.

Italy and France have a greater advantage in the process of adaptation to European policy. Their implication is noteworthy regarding the implantation of the structure of higher education in two cycles, with the introduction of the European credit system and in the use of the Diploma supplement, which in Italy has been compulsory since 2004-05, but in France is still only a recommendation.

In Spain provision has been made for the guidelines on convergence in the design of the new university policy, but this has not yet been implemented and is at present being debated and studied. Nevertheless, the regulations for the Diploma supplement and for Graduate and Postgraduate studies have been passed. 


\section{Notes}

1 This article forms part of the Research Project financed by the Consejería de Educación y Cultura de la Junta de Castilla y León (SA 141/04 entitled: "Convergences and Divergences in Teacher Training Systems in the European Union. Inicial Practical Training in France, Italy, Portugal and Spain.

2 Law no 9 of 20 January 1999, in force since 1999-2000: the "scuola di basi"

3 According to Law 144/ 1999 and Legislative Decree of 19 February 2004, general education is compulsory until age 15 and some kind of training is compulsory until age 18; this compulsory vocational education is aimed at increasing knowledge levels by diversifying the educational offer and including a vocational model.

4 In Canada and the USA, teacher training reforms have also been of concern to the authorities. Structural changes have been introduced, responsibility being held by different institutions (including the Ministry of Education and Universities) These changes relate to university curricula for teacher training and pedagogical models in both theoretical and practical aspects. Tardif, 2004:206).

5 In order to give new ímpetus to the $Z E P$, the Ministry of National Education has created the REP (Network of Priority Education) in order to increase action in sensitive areas. These networks cover over a thousand collèges and 7000 écoles. See Circular 2000/008, 8th February.

6 The competencies which the teacher must assess in the student are the following: the sequence is presented in a progression (11 competencies); the student will have kept lesson plans and a classroom diary with self-evaluation up to date, applied a coherent didactic account of what $s /$ he has learned (3 competencies), planned activities and situations as a function of the learning objectives ( 4 competencies), put into practice the teaching activity (6 competencies), written a training and assessment report ( 2 competencies) and analysed a learning situation (3 competencies).

7 In the case of Naples it deals with a Regional Specialization School ( SICSI).

8 The universities are: Università degli Studio Suor Orsola Benincasa; Università degli Studio di Napoli lórientale; Università degli Studi Napoli Federico II; Università degli Studi di Napoli; Università degli Studi di Napoli Parthenope.

9 Appendix 1.8. MURST Decree maggio 1998 in: Luzzato, G. (2000): Insegnare a insegnare, (Rome, Carocci), pp. 117 et seq.

10 Equivalent of the former Diploma di Maturita, which was replaced in 1998-99 by the Diploma istruzione secondaria superiore. As with the former, the new diploma is granted to students who pass the final examination at the end of the Secondary Education period.

11 According to the Ministerial Decree of 26th May 1998, entrance examinations are the responsibility of each university. Tests of logic and general culture are included, as well as literary history, science, mathematics and pedagogy and teaching methods.

12 Biancardi, F. and Sibilio, M (2003): Tirocinio e laboratorio. Della Recerca alla formaziones, Napoli, Gruppo Editoriales Eselibre.

13 This Statute was passed in 1994 by Decree-Law No. 16/94.

14 The establishment of the Instituto Piaget in the north-eastern area was authorised by means of Portaria No. 457-A/98, 29th of July.

15 The Instituto Piaget for the north-western area received official recognition by means of Decree-Law No. 271/89, 19th of August.

16 Vázquez Pérez, S., Clavell, M. and Eirín Nemiña, R.: "Sobre la profesionalización docente" in Políticas Educativas na Dimensión Europea, Universidade de Santiago de Compostela, 2002, p. 133.

17 Baccalaureate LOGSE-University entrance examination; Vocational Training - Technician Certificate; Advanced Specific Vocational Training- Higher Technician Certificate; University entrance examination for students over 25. 


\section{Bibliography}

Alves Baptista, María Isabel (2004): O ensino normal primario: currículo e politicas de formaçao, (Lisboa, Educa).

Alves Baptista, María Isabel (2003): "A prática pedagógica dos educadores e professores do $1^{\circ}$ ciclo: uma aposta na formaçao do Professional", EduSer, 1 , 83-108.

Alves Baptista, María Isabel (2004): A formaçao pratica dos professores em Portugal, (Lisboa, Colibrí).

Aprea, Valentina (2000): La scuola che non c'èe, (Firenze, Libri Liberal).

Bellengier, Ferdinand (2004): Le chef d'établissement privé et l'État, (Paris, Berger-Levrault), $3^{\mathrm{a}}$ ed.).

Cochran-Smith, M. y Lytle, S. (2002) : Dentrolfuera. Enseñantes que investigan. Madrid. Akal.

Dei, Marcelo (2000): La scuola in Italia, (Bologna, Il Mulino).

Dutercq, Ives (2005): Les régulations des politiques d'éducation, (Rennes, Presses Universitaires). Egido, I. (2000): Política educativa y autonomía escolar, (Madrid, Universidad Autónoma).

Eurydice (1996): Estructura de los sistemas educativos y de formación inicial en la Unión Europea, (Bruselas, Comisión Europea).

Eurydice (1999): CD-ROM.

Eurydice (2002): Las cifras clave de la educación en Europa (2002), (Bruselas, CE).

Eurydice (2003): Organización de la estructura de la enseñanza superior en Europa (2003/04) Tendencias nacionales en el marco del proceso de Bolonia (Bruselas, CE).

Fialaire, Jacques (1996): L'école en Europe, (París, Le Documentation Français).

Fernández de Castro, I. y Rogerio, J. (2001) : Escuela pública. Democracia y poder. Madrid. Miño y Dávila.

Ferrán F.; Nava, L.M.; Valle, J.M.(2004): Convergencias de la educación secundaria inferior e $n$ la Unión Europea, Madrid, CIDE.

García Garrido, J.L. (2005): Sistemas educativos de hoy, (Madrid, Ediciones Académicas).

García Garrido, J.L. (1998): Formación de maestros en Europa, en Rodríguez Marcos, A.; Sana Lobo, E. y Sotomayor Sáez, U. (Coord.): La formación de los maestros en los países de la Unión Europea, Madrid, Narcea.

Glasman, D. (2000): Des ZEP aux REP, (Toulouse, Editions Sedrap).

Gren, Andy; Leney, Tom y Wolf, Alison (2001): Convergencias y divergencias en los sistemas europeos de educación y formación profesional, (Barcelona, Editorial Pomares).

Heyning, Katharina E.: "Reforma de la formación del profesorado a la luz de los vínculos entre el Estado y la universidad. La política cultural de los textos", Historia cultural y educación, Barcelona, Pomares, 2003.

Langouët, G. y Léger, A. (2002): Escolaridad pública y privada en Francia: una investigación sobre elección familiar de la escuela, en Narodowski, M; Nores,

M. y Andrada, M: Nuevas tendencias en Políticas Educativas. Barcelona, Granica

Luzzato, G. (2000): Insegnare a insegnare, (Roma, Carocci).

Popkewitz, Thomas S.:"La producción de razón y poder: historia del currículum y tradiciones intelectuales", Historia cultural y educación, Barcelona, Pomares, 2003.

Robert, Andre D. et Terra, Herve (2000): Les IUFM et la formation des enseignants aujourd 'hui, (Paris, PUF).

Ruivo, Joáo (2003): "O Ensino Superior Politécnico em Portugal nos textos: historia de uma revoluçao tranquila”, Sarmiento (Anuario Galego de Historia da Educación), 7, pp. 177 204.

Tardif, M.(2004): Los saberes del docente y su desarrollo profesional. Madrid. Narcea.

Tooley, J. (2002): Justificación de las soluciones de mercado en educación, en Narodowski, M; Nores, M. y Andrada, M: Nuevas tendencias en Políticas Educativas. Barcelona, Granica Vaniscotte, Francine et Laderrière, Pierre (2002): L'école : horizon 2020, (Paris, L'Harmattan). 
Vega Gil, Leoncio : El docente del siglo XXI. Formación y retos pedagógicos. Revista Española de Educación Comparada, 5 (1999) 209-231.

Vonk, JHC.(2000) : El contexto social cambiante de la enseñanza en la Europa Occidental, en Biddle, B. ; Good, T.L.y Goodson, I.F. : La enseñanza y los profesores III. La reforma de la enseñanza en un mundo en transformación, Barcelona, Paidos.

Whitty, G., Power, S. y Halpin, D. (1999) : La escuela y el mercado, Madrid, Morata.

Zabalza Beraza, M.A. y otros (1996): Evaluación de experiencias y tendencias en la formación de profesorado, (Bilbao, Universidad de Deusto). 